Article

\title{
The NBA's Maximum Player Salary and the Distribution of Player Rents
}

\author{
Kelly M. Hastings and Frank Stephenson * \\ Department of Economics, Berry College, Box 5024, Mount Berry, GA 30149, USA; \\ E-Mail: kelly.hastings@vikings.berry.edu \\ * Author to whom correspondence should be addressed; E-Mail: efstephenson@berry.edu; \\ Tel.: +1-706-238-7878.
}

Academic Editor: Brian Soebbing

Received: 10 December 2014 / Accepted: 12 March 2015 / Published: 25 March 2014

\begin{abstract}
The NBA's 1999 Collective Bargaining Agreement (CBA) included provisions capping individual player pay in addition to team payrolls. This study examines the effect the NBA's maximum player salary on player rents by comparing player pay from the 1997-1998 and 2003-2004 seasons while controlling for player productivity and other factors related to player pay. The results indicate a large increase in the pay received by teams' second highest and, to a lesser extent, third highest paid players. We interpret this result as evidence that the adoption of the maximum player salary shifted rents from stars to complementary players. We also show that the 1999 CBA's rookie contract provisions reduced salaries of early career players.
\end{abstract}

Keywords: NBA; maximum player salary; 1999 collective bargaining agreement; rookie contract

JEL Classification: Z22 
They arrived at this specific point after salaries ballooned over the past 15 years - not for superstars, but for complementary players who don't sell tickets, can't carry a franchise, and, in a worst-case scenario, operate as a sunk cost...

It's about Andre Iguodala, Emeka Okafor, Elton Brand, Andrei Kirilenko, Tyson Chandler, Larry Hughes, Michael Redd, Corey Maggette and Luol Deng making eight figures a year but being unable to sell tickets, create local buzz or lead a team to anything better than 35 wins.

—Bill Simmons (2010) [1]

\section{Introduction}

A prominent feature of the 1999 Collective Bargaining Agreement (CBA) between National Basketball Association's (NBA) owners and players was the imposition of a maximum player salary. Previously teams re-signing their own free agents had been allowed to pay those any amount that was mutually agreeable to the teams and players regardless of the NBA's salary cap. Likewise, the 1999 CBA reduced the pay going to early-career players subject to so-called rookie contracts. With superstar players no longer able to negotiate unlimited salaries with their teams and rookie contract players receiving less pay, some of the revenues generated by those players were available to be captured by team owners, other players, or other providers of NBA inputs. This paper investigates the possibility that the rents were (at least partially) captured by other players, particularly those referred to by basketball commentator Bill Simmons as "complementary players" in the quotation above [1]. ${ }^{1}$ We begin with an overview of the 1999 CBA before turning to our empirical model and results.

\section{The 1999 Collective Bargaining Agreement ${ }^{2}$}

In their $1983 \mathrm{CBA}$, the NBA and its players agreed to impose a salary cap on teams with no limit on individual player salaries. However, the cap contained many exceptions, most notably a team's right to re-sign its players even if doing so put it over the salary cap. ${ }^{3}$ The combination of unlimited player salaries and teams' ability to re-sign their players led team wage bills to frequently exceed the cap.

Because of escalating player expenses, the NBA won a provision in the 1995 CBA allowing the league to re-open the labor agreement if total player compensation exceeded $51.8 \%$ revenue (referred to as "basketball-related income"). After player pay exceeded the $51.8 \%$ threshold in the 1997-1998 season, the league exercised its right to re-open the CBA and locked the players out

1 That the NBA's 1999 collective bargaining agreement was expected to redistribute rents away from superstars toward other players was explained by Hill and Groothuis [2]. They argue that, consistent with previous research in labor economics, the redistribution of rents can be explained by a median voter model of union membership.

2 This section is based on [2-4].

3 Teams' ability to offer their free agent players unlimited pay regardless of salary cap implications was sometimes referred to as the Larry Bird Exception. However, the 1999 Collective Bargaining Agreement still contained provisions, sometimes referred to as "Bird Rules," permitting teams to pay their free agents more than the players could earn by moving to other teams but no longer allowing unlimited player pay. Because of the potential for confusion between the so-called Bird Exception and Bird Rules, this paper does not use those terms. 
effective 1 July 1998. The lockout lasted longer than six months and caused the 1998-1999 season to be shortened from 82 to 50 games before the league and its players agreed to a new CBA in early 1999 .

The 1999 CBA contained many significant changes to the NBA's labor-management environment. The most important features for the purposes of this paper were the CBA's imposition of maximum individual player salaries, reduced pay for players in their first contracts after entering the league (so-called "rookie contracts"), and a new "midlevel" team salary cap exception that would be equal to $108 \%$ of the mean salary after a phase-in period during the first years of the CBA. ${ }^{4}$ The maximum player salary depends on experience, topping out at the maximum of $35 \%$ of the team cap, $105 \%$ of the player's previous salary, or $\$ 14$ million for players with at least 10 years of experience. Although existing player contracts would be "grandfathered" from the maximum player salary provisions, the new caps meant that superstar pay such as Michael Jordan's salary in excess of \$30 million would be a thing of the past as these players left the league. Likewise, the new CBA's rookie contract provisions reduced the slot amounts going to rookie players, ${ }^{5}$ stopped allowing players to negotiate lucrative contract extensions after only two seasons in the league, and extended team control from three to five years by granting teams an option year for fourth year players and the right of first refusal for fifth-year players. By limiting player pay for stars and for early-career players, the 1999 CBA redistributed rents that would have gone to these players. This paper tests the conjecture that rents were captured, at least in part, by complementary players, such as those listed in Bill Simmons quote [1].

\section{Empirical Framework}

To assess the possibility that imposing maximum player salaries led to rents for complementary players, this paper compares player salaries from the 1997-1998 and 2003-2004 seasons. The 1997-1998 season was the last full season played under the CBA permitting unlimited payment by teams re-signing their free agents. The 1999 CBA allowed existing contracts to be honored, hence, our choice of a comparison season that comes five years after the new collective bargaining agreement went into effect. Most, though perhaps not all, 2003-2004 player salaries should have been negotiated under the new rules promulgated by the 1999 CBA. ${ }^{6}$ The analysis focuses on the salary earned by the 250 highest paid players (and ties) in each year, yielding a pooled sample size of 507 . Using the 250 highest paid players corresponds roughly to the eight highest paid players per team in each year.

The dependent variable for the analysis, RSAL, is each player's inflation-adjusted salary. The nominal salary data for both years are obtained from Rod Fort's sports data website [8]. ${ }^{7}$ The $1997-1998$

4 Other notable provisions included minimum player salaries that escalated with player experience, a luxury tax imposed on teams exceeding the team salary cap, and a salary recovery provision allowing team owners to "clawback" some player pay if aggregate salaries exceed certain basketball-related income thresholds.

5 Drafted player pay is determined by their "slot" or position taken in the draft.

6 In examining contemporaneous salaries, our approach follows that of papers such as $[5,6]$ in ignoring whether players had multi-year contracts and the year in which those contracts were signed. Jenkins [7] points out that using contemporaneous salary and contemporaneous productivity is potentially problematic because actual productivity may not match the anticipated productivity at the time a multi-year contract was signed. In any event, we know of no comprehensive source for data on the length or signing dates of NBA player contracts.

7 Fort indicates that the salary data were originally published by USA Today. 
salaries are then converted to their inflation-adjusted 2003-2004 equivalents using the CPI. Descriptive statistics for RSAL and all explanatory variables are reported in Table 1.

Table 1. Descriptive Statistics.

\begin{tabular}{ccccc}
\hline Variables & Mean & Std. Dev. & Minimum & Maximum \\
\hline Dependent & & & & \\
RSAL & $4,758,353$ & $4,001,079$ & $37,938,672$ & $37,938,672$ \\
Independent & & & & \\
WS/48 & 0.099 & 0.059 & -0.186 & 0.316 \\
PPG & 11.11 & 6.02 & 0.80 & 32.10 \\
MIN & 1855 & 879 & 6 & 3485 \\
EXPERIENCE & 6805 & 3.660 & 0 & 19 \\
HEIGHT & 79.301 & 3.787 & 63 & 90 \\
$1^{\text {st }}$ & 0.114 & 0.319 & 0 & 1 \\
$2^{\text {nd }}$ & 0.114 & 0.319 & 0 & 1 \\
$3^{\text {rd }}$ & 0.114 & 0.319 & 0 & 1 \\
$4^{\text {th }}$ & 0.114 & 0.319 & 0 & 1 \\
ROOKIECONTRACT & 0.205 & 0.404 & 0 & 1 \\
DV2003 & 0.504 & 0.500 & 0 & 1 \\
CTR & 0.223 & 0.417 & 0 & 1 \\
PF & 0.217 & 0.413 & 0 & 1 \\
SG & 0.185 & 0.389 & 0 & 1 \\
PG & 0.181 & 0.386 & 0 & 1 \\
\hline
\end{tabular}

To control for player quality, the model includes win shares per forty-eight minutes played (WS/48) which is a measure of the number of wins contributed by a player based on his offensive and defensive performance. These data are obtained from basketball-reference.com where additional details about the calculation of win shares can be found. Since better players should have larger salaries than less talented players, WS/48 should be positively correlated with RSAL. The model also includes minutes played (MIN) during the season; ceteris paribus, players who play more should be more valuable to their teams, resulting in a positive coefficient on MIN. These data are also obtained from basketball-reference.com [9]. In an alternate specification, we use points per game (PPG) instead of win shares because Berri et al. [10] find scoring is more strongly related to player salaries than are other measures of performance such as rebounds, steals, and assists.

HEIGHT (in inches) is included in the model because Berri et al. [11] implies that taller players should receive a pay premium because of their relative scarcity. Likewise, the model includes EXPERIENCE (in years) and its square (EXPERIENCESQ) to capture the relationship between experience and pay. Including both experience and its square is common in studies of athlete pay because it is expected that players will improve as they gain experience during the early years of their careers before eventually having performance decline because of age or competitive wear-and-tear. Beyond this usual rationale for including experience and experience squared in the model, it is 
important to do so because, as noted above, the 1999 CBA adopted both minimum and maximum salaries that increased with experience. ${ }^{8}$

The variables $1^{\text {st }}, 2^{\text {nd }}, 3^{\text {rd }}$, and $4^{\text {th }}$ are dummies for the first, second, third, and fourth highest paid players on a given team, respectively. Since the model already includes a measure of player productivity (WS/48), the coefficients on these dummy variables can be thought of as measures of rents captured by the highest paid players on each team. ${ }^{9}$ DV2003 is a dummy variable that takes a value of one for all 2003-2004 season observations and a value of zero for all 1997-1998 season observations. A positive correlation between DV2003 and RSAL would indicate that NBA player salaries have increased over time (even after adjusting for inflation). The model also includes four interaction terms ( $1^{\text {st }} *$ DV2003 etc.) between the rank dummies and the 2003-2004 dummy variable. The estimated coefficients on these interaction terms would be interpreted as the change in the rents accruing to the highest, second highest, third highest, and fourth highest paid players, respectively, in 2003-2004 relative to 1997-1998. Our conjecture, as discussed above, is that the 1999 CBA increased the rents accruing to a team's complementary players rather than the highest paid player on each team.

The model also includes a dummy variable ROOKIECONTRACT for players in their first contract after being drafted. Since the 1999 CBA reduced slot amounts for early-career players and extended the duration of team control, the model also includes an interaction term ROOKIECONTRACT * DV2003 to capture any change in rookie pay following the new CBA. Lastly, in some specifications, the model also includes dummy variables for player positions in case there are systematic pay differences across positions. ${ }^{10}$ The included variables are dummies for centers (CTR), power forwards (PF), shooting guards (SG), and point guards (PG), with small forwards as the reference category. The player position data were also obtained from basketball-reference.com [9].

\section{Estimation Results}

Table 2 contains OLS regression results; the parentheses contain t-statistics derived from White-corrected standard errors. The results in columns 1 and 3 use win shares as the measure of player performance while the estimations reported in columns 2 and 4 use points per game. Columns 1 and 2 are estimated without position dummies (center, power forward, etc.) while columns 3 and 4 include the position dummies.

8 That mandating pay increase with experience could incentivize teams to substitute less experienced players for more experienced players is supported by Ducking et al. [12].

9 Kendall [13] takes this approach to examining player misbehavior and finds that a player's pay rank on his team has a strong relationship with the number of technical fouls received.

10 A possible reason for systematic pay differences is the finding by Berri et al. [11] that the scarcity of talented tall players (centers or perhaps power forwards) is a source of competitive imbalance in the NBA. 
Table 2. Regression Results.

\begin{tabular}{|c|c|c|c|c|}
\hline Variable & (1) & (2) & (3) & (4) \\
\hline $\mathrm{WS} / 48$ & $\begin{array}{c}11,448,470 * \\
(3.53)\end{array}$ & & $\begin{array}{c}11,570,400 * \\
(3.48)\end{array}$ & \\
\hline PPG & & $\begin{array}{c}205,665 * \\
(4.01)\end{array}$ & & $\begin{array}{c}214,282 * \\
(4.20)\end{array}$ \\
\hline MIN & $\begin{array}{l}137.10 \\
(1.10)\end{array}$ & $\begin{array}{c}-513.83 * \\
(-2.22)\end{array}$ & $\begin{array}{l}111.92 \\
(0.85)\end{array}$ & $\begin{array}{c}-522.89 * \\
(-2.31)\end{array}$ \\
\hline EXPERIENCE & $\begin{array}{c}448,316^{*} \\
(4.05)\end{array}$ & $\begin{array}{c}485,442 * \\
(4.06)\end{array}$ & $\begin{array}{c}452,496 * \\
(4.09)\end{array}$ & $\begin{array}{c}482,232 * \\
\quad(4.01)\end{array}$ \\
\hline EXPERIENCESQ & $\begin{array}{c}-19,835 * \\
(-2.93)\end{array}$ & $\begin{array}{c}-19,960 * \\
(-2.65)\end{array}$ & $\begin{array}{c}-19,818 * \\
(-2.92)\end{array}$ & $\begin{array}{c}-19,771 * \\
(-2.61)\end{array}$ \\
\hline HEIGHT & $\begin{array}{c}45,934 * \\
(1.69) \\
\end{array}$ & $\begin{array}{c}73,983 * \\
(2.88) \\
\end{array}$ & $\begin{array}{c}99,898 * \\
(2.17) \\
\end{array}$ & $\begin{array}{c}74,870 * \\
(1.66) \\
\end{array}$ \\
\hline $1^{\text {st }}$ & $\begin{array}{c}6,801,080 * \\
(5.95)\end{array}$ & $\begin{array}{c}5,954,402 * \\
(5.68)\end{array}$ & $\begin{array}{c}6,795,856 * \\
(5.95)\end{array}$ & $\begin{array}{c}5,849,532 * \\
(5.54)\end{array}$ \\
\hline $2^{\text {nd }}$ & $\begin{array}{c}2,663,831 * \\
(8.35)\end{array}$ & $\begin{array}{c}2,202,278 * \\
(5.71)\end{array}$ & $\begin{array}{c}2,671,115 * \\
(8.43)\end{array}$ & $\begin{array}{c}2,169,702 * \\
(5.51)\end{array}$ \\
\hline $3^{\text {rd }}$ & $\begin{array}{c}1,802,492 * \\
(6.98)\end{array}$ & $\begin{array}{c}1,662,274 * \\
(6.12)\end{array}$ & $\begin{array}{c}1,806,055 * \\
(7.21)\end{array}$ & $\begin{array}{c}1,674,239 * \\
(5.96)\end{array}$ \\
\hline $4^{\text {th }}$ & $\begin{array}{c}783,174 * \\
(3.37)\end{array}$ & $\begin{array}{c}931,056 * \\
(3.75) \\
\end{array}$ & $\begin{array}{c}766,748 * \\
(3.26) \\
\end{array}$ & $\begin{array}{c}926,015 * \\
(3.65) \\
\end{array}$ \\
\hline ROOKIECONTRACT & $\begin{array}{c}572,744 * \\
(1.68)\end{array}$ & $\begin{array}{c}247,285 \\
(0.74) \\
\end{array}$ & $\begin{array}{c}613,638 * \\
(1.81)\end{array}$ & $\begin{array}{c}243,901 \\
(0.73) \\
\end{array}$ \\
\hline DV2003 & $\begin{array}{c}1,128,398 * \\
(5.73)\end{array}$ & $\begin{array}{c}1,363,341 * \\
(7.14)\end{array}$ & $\begin{array}{c}1,127,071 * \\
(5.59)\end{array}$ & $\begin{array}{c}1,341,995 * \\
(6.92)\end{array}$ \\
\hline $1^{\text {st } *}$ DV2003 & $\begin{array}{c}1,903,845 \\
(1.34)\end{array}$ & $\begin{array}{c}1,627,122 \\
(1.15)\end{array}$ & $\begin{array}{c}1,914,272 \\
(1.32)\end{array}$ & $\begin{array}{c}1,716,194 \\
(1.19) \\
\end{array}$ \\
\hline $2^{\text {nd }} *$ DV 2003 & $\begin{array}{c}2,772,432 * \\
(4.40)\end{array}$ & $\begin{array}{c}2,492,349 * \\
(3.78)\end{array}$ & $\begin{array}{c}2,771,133 * \\
(4.38)\end{array}$ & $\begin{array}{c}2,559,076^{*} \\
(3.88)\end{array}$ \\
\hline $3^{\text {rd }} *$ DV2003 & $\begin{array}{c}1,053,477 * \\
(1.95)\end{array}$ & $\begin{array}{c}909,989 * \\
(1.69) \\
\end{array}$ & $\begin{array}{c}1,026,794 * \\
(1.90)\end{array}$ & $\begin{array}{c}843,480 \\
(1.56) \\
\end{array}$ \\
\hline $4^{\text {th }} *$ DV2003 & $\begin{array}{c}761,291 * \\
(1.77)\end{array}$ & $\begin{array}{c}405,425 \\
(0.95) \\
\end{array}$ & $\begin{array}{c}790,390 * \\
(1.85)\end{array}$ & $\begin{array}{c}416,236 \\
(0.98) \\
\end{array}$ \\
\hline ROOKIECONTRACT * DV2003 & $\begin{array}{c}-638,726 * \\
(-2.11) \\
\end{array}$ & $\begin{array}{c}-676,659 * \\
(-2.25)\end{array}$ & $\begin{array}{c}-690,485 * \\
(-2.26)\end{array}$ & $\begin{array}{c}-649,338 * \\
(-2.13) \\
\end{array}$ \\
\hline CTR & & & $\begin{array}{c}-299,661 \\
(-0.94) \\
\end{array}$ & $\begin{array}{c}294,576 \\
(0.92) \\
\end{array}$ \\
\hline $\mathrm{PF}$ & & & $\begin{array}{c}-236,912 \\
(-0.81)\end{array}$ & $\begin{array}{r}52,520 \\
(0.19)\end{array}$ \\
\hline SG & & & $\begin{array}{l}-3131 \\
(-0.01) \\
\end{array}$ & $\begin{array}{c}-146,332 \\
(-0.38)\end{array}$ \\
\hline PG & & & $\begin{array}{c}398,326 \\
(1.11)\end{array}$ & $\begin{array}{c}325,586 \\
(0.89)\end{array}$ \\
\hline Constant & $\begin{array}{c}-4,502,654 * \\
(-2.05)\end{array}$ & $\begin{array}{c}-6,755,296 \\
* \\
(-3.18)\end{array}$ & $\begin{array}{c}-8,731,644 * \\
(-2.33)\end{array}$ & $\begin{array}{c}-6,985,388 * \\
(-1.91)\end{array}$ \\
\hline $\mathrm{R}^{2}$ & 0.672 & 0.681 & 0.673 & 0.683 \\
\hline
\end{tabular}

Notes: Parentheses contain $t$-statistics derived from White-corrected standard errors. ${ }^{*}$ Indicates $p<0.10$. 
As expected, player pay is strongly related to performance whether measured by win shares or points per game. Likewise, the positive coefficient on EXPERIENCE and negative coefficient on EXPERIENCESQ indicates that there are diminishing marginal returns to experience; the maximum effect of experience occurs at about 12 years of experience. An additional inch of height is associated with a salary increase of $\$ 45,000-\$ 100,000$.

ROOKIECONTRACT has a positive coefficient, though it is statistically significant only in the win share specifications. That early-career players prior to the 1999 CBA were reaping pay of up to $\$ 600,000$ in excess of their productivity might explain why that labor agreement reduced the pay for players playing under their first contracts. The negative coefficient on ROOKIECONTRACT * DV2003 indicates that the $1999 \mathrm{CBA}$ reduced highly paid early-career players' salaries by about $\$ 650,000$. There is little evidence of systematic salary differences based on position as found in Berri et al. [10], but this result may be caused by including HEIGHT as an explanatory variable.

The coefficient on $1^{\text {st }}$ indicates that the top paid players were earning large salaries even after controlling for their productivity. The coefficient on $1^{\text {st }}$ is more than twice as large as the coefficient on $2^{\text {nd }}$ and more than triple the coefficient on $3^{\text {rd }}$ in the specification. As for the effects of the 1999 CBA, the coefficient on DV2003 indicates that salaries rose by more than $\$ 1$ million on average (even after adjusting for inflation). However, the rank-year interaction terms $\left(1^{\text {st }} *\right.$ DV2003, etc.), especially in the win share specifications, indicate large gains for complementary players. Comparing $2^{\text {nd } *}$ DV2003 to $2^{\text {nd }}$ indicates that the gains to the second ranked players more than doubled. Similar comparisons indicate that pay for third ranked and, in some specifications, fourth ranked players increased by more than $50 \%$. The gains to star players are much smaller (about one-fourth) and are imprecisely estimated. Hence, the estimation results are consistent with the conjecture that the 1999 CBA shifted the distribution of player pay toward complementary players, particularly the second highest paid players on each team. The results, therefore, may help explain Bill Simmons's observation [1] about the high pay of complementary players, such as Elton Brand and Luol Deng.

\section{Conclusions}

A formal model for why the rents should accrue to complementary players instead of going to other input suppliers (e.g., coaches) or to team owners is beyond the scope of this short paper, but tournament theory [14] is the implicit basis underlying our conjecture that the individual salary cap redistributed rents to complementary players. In tournament theory, compensation rests not only on productivity but on rank order. In our context, the maximum player salary could be viewed as a mechanism that attenuates the return to being the top ranked player on a team thereby allowing for the redistribution of those rents.

In college sports, economists hypothesize that rents derived from not paying college athletes lead to increased compensation for coaches or to more lavish athletic facilities [15,16]. For example, Andrew Zimbalist (quoted in Nocera 2007 [17]) states, "Since the players don't get paid, you can't just go out and hire the Tom Bradys of college sports, so instead (colleges) throw money at everything else." Although the notion that coaches or others capture the rents generated by unpaid college athletes may be widely accepted, we know of no empirical tests of this hypothesis. The lack of empirical testing is 
probably the result of there not being any rule changes regarding payment of athletes or other empirical frameworks appropriate for such tests.

In the NBA, however, evidence suggests that coaches have little effect on player performance [18]. Thus it would make little sense to expect rents created from capping individual player salaries to flow to NBA coaches. Under the 1999 CBA, therefore, the most productive NBA resource for which pay could be bid up might have been role players, such as Brand and Deng, who were not earning the league's maximum allowable salary. This paper's findings that imposing maximum player salaries led to a large increase in pay for the second and third highest paid players on NBA teams is consistent with the conjecture that the 1999 CBA led to a shift in rents from star players to complementary players.

\section{Author Contributions}

Both authors contributed to the data collection, empirical analysis, and writing of this paper.

\section{Conflicts of Interest}

The authors declare no conflict of interest.

\section{References}

1. Simmons, B. A Fan-Friendly Solution to Fix the NBA. ESPN.com. 24 February 2010. Available online: http://sports.espn.go.com/espn/page2/story?page=simmons/100224 (accessed on 18 March 2015).

2. Hill, J.R.; Groothuis, P.A. The new NBA collective bargaining agreement, the median voter model, and a Robin Hood rent redistribution. J. Sports Econ. 2001, 2, 131-144.

3. Beck, H. For N.B.A. owners, 1999 labor deal was win with regrets. New York Times, 3 July 2011, p. SP6.

4. Kaplan, R.A. The NBA luxury tax model: A misguided regulatory regime. Columbia Law Rev. 2004, 104, 1615-1650.

5. Hakes, J.K.; Sauer, R.D. An economic evaluation of the moneyball hypothesis. J. Econ. Perspect. 2006, 20, 173-186.

6. Bradbury, J.C. Does the baseball labor market properly value pitchers? J. Sports Econ. 2007, 8, 616-632.

7. Jenkins, J.A. A reexamination of salary discrimination in professional basketball. Soc. Sci. Q. 1996, 77, 594-608.

8. Rod Fort's Sports Data Website. Available online: https://sites.google.com/site/rodswebpages/codes (accessed on 18 March 2015).

9. Basketball-Reference.com. Available online: http://www.basketball-reference.com/ (accessed on 18 March 2015).

10. Berri, D.J.; Brook, S.L.; Schmidt, M.B. Does one simply need to score to score? Int. J. Sport Finance 2007, 2, 190-205.

11. Berri, D.J.; Brook, S.L.; Frick, B.; Fenn, A.J.; Vicente-Mayoral, R. The short supply of tall people: Competitive imbalance and the National Basketball Association. J. Econ. Issues 2005, 39, 
$1029-1041$.

12. Ducking, J.; Groothuis, P.A.; Hill, J.R. Minimum pay scale and career length in the NBA. Ind. Relat. J. Econ. Soc. 2014, 53, 617-635.

13. Kendall, T.D. Celebrity misbehavior in the NBA. J. Sports Econ. 2008, 9, 231-249.

14. Lazear, E.P.; Rosen, S. Rank-order tournaments as optimum labor contracts. J. Polit. Econ. 1981, 89, 841-864.

15. Kahn, L.M. Cartel behavior and amateurism in college sports. J. Econ. Perspect. 2007, 21, 209-226.

16. Farmer, A.; Pecorino P. Is the coach paid too much? Coaching salaries and the NCAA cartel. J. Econ. Manag. Strategy 2010, 19, 841-862.

17. Nocera, J. Skybox U. New York Times, 28 October 2007, p. 38.

18. Berri, D.J.; Leeds, M.A.; Leeds, E.M.; Mondello, M. The role of managers in team performance. Int. J. Sport Finance 2009, 4, 75-93.

(C) 2015 by the authors; licensee MDPI, Basel, Switzerland. This article is an open access article distributed under the terms and conditions of the Creative Commons Attribution license (http://creativecommons.org/licenses/by/4.0/). 